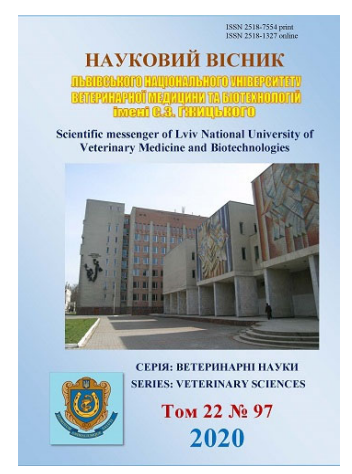

\section{Науковий вісник Дьвівського національного університету ветеринарної медицини та біотехнологій імені С.3. Гжицького.}

\author{
Серія: Ветеринарні науки
}

\author{
Scientific Messenger of Lviv National University \\ of Veterinary Medicine and Biotechnologies. \\ Series: Veterinary sciences
}

doi: $10.32718 /$ nvlvet9716 https://nvlvet.com.ua/index.php/journal

UDC 343.58: 340.69: 636.09

\title{
Recent advances in forensic veterinary examination of animals affected by violent attitude
}

\author{
I. V. Yatsenko, O. I. Parilovskyi \\ Kharkiv State Zooveterinary Academy, Kharkiv, Ukraine
}

Article info

Received 07.02.2020

Received in revised form 05.03 .2020

Accepted 06.03.2020

Kharkiv state zooveterinary academy, Mala Danilivka.

Dergachi district, Kharkiv region, 62341, Ukraine.

Tel.: +38-067-186-06-65

E-mail: yacenko-1971@ukr.net
Yatsenko, I. V., \& Parilovsky, O. I. (2020). Recent advances in forensic veterinary examination of animals affected by violent attitude. Scientific Messenger of Lviv National University of Veterinary Medicine and Biotechnologies. Series: Veterinary sciences, 22(97), 95-105. doi: $10.32718 /$ nvlvet9716

The article is formulated and systematized with some issues of cruel atitude to animals in the aspect of forensic veterinary examination. It is proved that the main directions of improving the forensic veterinary examination of live animals affected by cruelty or corpses of animals with signs of violent death from cruelty are the development, approval and implementation of regulatory legal acts on forensic veterinary determination of the severity of bodily harm, judicial veterinary examination of live animals, forensic veterinary examination of a corpse of an animal, automation and optimization of the process of registration of results examination, and the use of advanced Information Technologies in forensic veterinary examination. The proposed authors' edition of the definition of "animal cruelty" for the criminal qualification of this offense. The novelty of defenition is what we proposed to consider as a consequence of animal cruelty not only the injury or death of the animal, but also severe damage or other disruption to its health. The content and justified consequences of cruelty to animals that are the subject of a forensic veterinary examination are disclosed. The consequences of cruelty to animals include not only the injury or death of the animal, but also severe injuries or other health problems. It was given a list of injuries (injuries) that are severe and life-threatening to the animal at the time of infliction and threaten the death of the animal; threat of loss, or the loss of any organ or the loss by an organ of its functions. We proposed to indicative list of issues that can be put to the decision of a forensic expert by a court or investigator during a study of a live animal that has been injured from abuse or a corpse of an animal with signs of violent death should be added as an addition to the "Scientific and methodological recommendations on the preparation and appointment of forensic examinations and expert studies "for their practical use by law enforcement agencies. The qualification of an animal cruelty violation must be taken into account the opinion of the forensic veterinarian on the nature and severity of bodily harm, as well as the causal link between the injuries identified by the expert and the health condition or death of the animal. The criterion for differentiating an administrative and a criminal offense from cruelty to animals is solely the presence or absence of bodily harm, which is ascertained exclusively by a forensic veterinarian.

Key words: forensic veterinary examination, areas of improvement, cruel attitude to animals.

\section{Новітні досягнення в судово-ветеринарній експертизі тварин, постраждалих від жорстокого поводження}

\author{
I. В. Яценко, О. І. Париловський
}

Харківська державна зооветеринарна академія, м. Харків, Украӥна

В роботі сформульовано $і$ систематизовано деякі питання жорстокого поводження з тваринами в аспекті судововетеринарної експертизи. Доведено, щзо напрямами вдосконалення судово-ветеринарної експертизи живих тварин, постраждалих від жорстокого поводження, чи трупів тварин з ознаками насильницької смерті від жорстокого поводження є розробка, затвер- 
дження і впровадження в практику нормативно-правових актів щчодо судово-ветеринарного визначення ступеня тяжкості тілесних ушкоджень, судово-ветеринарної експертизи живих тварин, судово-ветеринарної експертизи трупа тварини, автоматизації й оптимізаиї проиесів оформлення результатів експертизи, використання новітніх інформаційних технологій в судововетеринарній експертизі. Запропонована авторська редакція дефінічії “жорстоке поводження з тваринами” за кримінальної кваліфікації иьього правопорушення. Новелою дефеніції є те, шчо нами запропоновано вважати наслідком жсрстокого поводження з тваринами не лише каліцтво чи смерть тварини, а й ушкодження чи інший розлад ї̈ здоров'я тяжкого ступеня. Розкрито зміст i обтрунтовано наслідки жорстокого поводження з тваринами, які є предметом судово-ветеринарної експертизи. До наслідків жорстокого поводження з тваринами варто зачислити не лише каліцтво чи смерть тварини, а й ушкодження чи інший розлад ї̈ здоров'я тяжкого ступеня. Наведено перелік ушкоджень (травм), які належать до тяжких $і$ є небезпечними для життя тварини в момент заподіяння $i$ загрожують загибеллю тварини; є загроза втрати або відбулась втрата будь-якого органа або втрата органом його функиій. Запропонований нами орієнтовний перелік питань, які можуть бути поставлені на вирішення судововетеринарного експерта судом чи слідчим під час дослідження живої тварини, постраждалої від жорстокого поводження, чи трупа тварини з ознаками насильницької смерті необхідно внести як доповнення до “Науково-методичних рекомендацій з питань підготовки і призначення судових експертиз та експертних досліджень” для їхнього практичного використання правоохоронними органами. Кваліфікація правопорушення жорстокого поводження з тваринами має враховувати висновок судово-ветеринарного експерта щуодо характеру та ступеня тяжкості тілесних ушкоджень, а також причинно-наслідковий зв'язок між виявленими експертом ушкодженнями і розладом здоров'я чи смертю тварини.

Ключові слова: судово-ветеринарна експертиза, напрями вдосконалення, жорстоке поводження з тваринами.

\section{Ветуп}

Демократія кожної розвиненої країни світу приділяє значну увагу правам тварин та їх захисту від насильства, жорсткого поводження, каліцтва й необгрунтованого винищення (de Almeida Silva et al., 2016; Zapara et al., 2019).

Світова спільнота підтвердила своє бажання захищати тварин від протиправних посягань, втіливши ці наміри в ряді Свропейських конвенцій, регламентів, декларацій (Priest, 2019).

Це обумовлено тим, що хребетні тварини здатні відчувати фізичні й психічні страждання, тому будьяке їх використання не повинно супроводжуватися спричиненням болю, страху, пригніченням стану чи іншим дискомфортом (Ward \& Hosey, 2019; Traini, 2019).

Нині у багатьох країнах світу створено інститут захисту прав тварин, удосконалюються механізми їхньої реалізації, прийнято нові нормативно-правові акти.

В 2006 р. в Україні прийнято Закон "Про захист тварин від жорстокого поводження" (Zakon Ukrainy vid 21.02.2006 № 3447-IV), а в 2017 році суттєво посилено адміністративну й кримінальну відповідальність за жорстоке поводження з тваринами (Zakon Ukrainy vid 04.08.2017). Проте випадки таких правопорушень нині залишаються численними. Так, кількість облікованих правопорушень, передбачених статтею 299 Кримінального кодексу України з 2006 по 2019 роки збільшилась у 9,4 разу.

Так, згідно зі статичною звітністю Управління організованого забезпечення ЄРДР та інформаційноаналітичної роботи Генеральної прокуратури України (Statychna zvitnist Upravlinnia orhanizovanoho zabezpechennia YeRDR...) за 2006-2019 pp. правоохоронними органами було виявлено i обліковано 1000 злочинів жорстокого поводження 3 тваринами, з них за останні 5 років (з 2015 по 2019 роки) - 662 злочинів, що становить 66,2 \% (рис. 1-2).

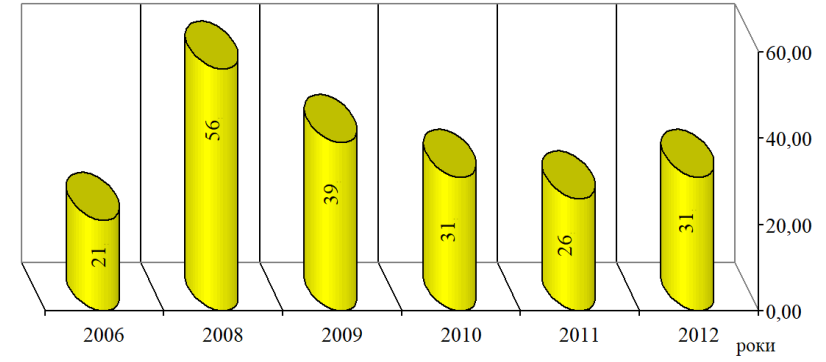

Рис. 1. Кількість злочинів, передбачених ст. 299 КК

України, облікованих в Україні за 2006-2019 рр.

За останні п'ять років, тобто з 2015 по 2019 роки, правоохоронними органами обліковано 669 правопорушень, передбачених ст. 299 КК України (рис. 2). За цей період кількість зазначених правопорушень збільшилась в 2,8 разу, тобто на $181,4 \%$.

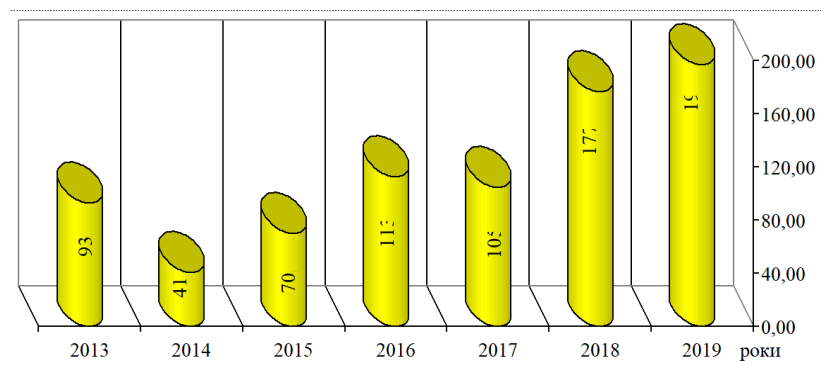

Рис. 2. Кількість злочинів, передбачених ст. 299 КК

України, облікованих в Україні за 2013-2019 рр.

Таким чином, аналіз цієї інформації свідчить про те, що кількість зафіксованих злочинних діянь щодо жорстокого поводження 3 тваринами збільшилася, що в черговий раз підтверджує актуальність обраного нами напряму дослідження.

Наукові дослідження щодо адміністративно чи кримінально-правової характеристики проблеми жорстокого поводження 3 тваринами проводили вченіюристи: С. Ф. Денисов зі співавт. (Denysov \& Kulyk, 2003), А. В. Ландіна (Landina, 2005), I. I. Лобов (Lobov, 2000), I. А. Головко (Holovko, 2010), В. О. Турська (Turska, 2016), М. В. Вербіцька (Verbitska, 2014), Д. О. Калмиков із співавт. 
(Kalmykov et al., 2013), I. Б. Медицький (Medytskyi, 2014), О. С. Чорна (Chorna, 2010), Д. О. Антонюк (Antoniuk, 2014), О. О. Шуміло (Shumilo, 2016), C. П. Репецький (Repetskyi, 2010). Проте в процесі досудового розслідування цього правопорушення велике значення відводиться судовій експертизі як одному із засобів доказування (Cooper et al., 1998; Cooper et al., 2008; Benetato et al., 2011; McEwen, 2012; Gerdin \& McDonough, 2013; de Siqueira et al., 2016; Bradley-Siemens \& Brower, 2016; Lockwood et al., 2019).

За допомогою судово-ветеринарної експертизи встановлюють ознаки і ступінь розладу здоров'я, ступінь тілесних ушкоджень, ознаки каліцтва або визначають причину смерті тварини як наслідок ушкоджень в результаті жорстокого поводження 3 нею, причинно-наслідкові зв'язки, що і передбачено диспозицією ст. 299 КК України (Yatsenko et al., 2019). Проте в Україні відсутні теоретичні розробки та розлоге емпіричне дослідження цієї проблеми вченими-юристами та лікарями ветеринарної медицини. На відміну від судово-медичної експертизи, де всі дії 3 об'єктами дослідження регламентовані чинними нормативно-правовими актами, в судововетеринарній експертизі подібне регулювання відсутне.

Крім того, нині:

- не визначені критерії ступеня тяжкості тілесних ушкоджень тварин;

- не розроблені правила судово-ветеринарної експертизи живих тварин;

- відсутні правила проведення судововетеринарної експертизи трупів тварин 3 ознаками насильницької смерті, в т. ч. від жорстокого поводження;

- не розкрито особливостей оформлення й оцінки результатів судово-ветеринарної експертизи тварин.

Таким чином, обгрунтування напрямів вдосконалення судово-ветеринарної експертизи тварин, постраждалих від жорстокого поводження, $є$ актуальним, має теоретичне й практичне значення як в юриспруденції, так і у ветеринарній медицині.

Мета роботи - окреслити та обгрунтувати напрями вдосконалення судово-ветеринарної експертизи тварин, постраждалих від жорстокого поводження.

\section{Матеріал і методи досліджень}

3 урахуванням специфіки теми, мети і завдань дослідження в роботі використано наукові методи, зокрема: формально-юридичний, діалектичний, порівняльно-правовий, системного аналізу, логікограматичний, статистичний, моделювання, аналіз висновків судово-ветеринарних експертиз.

Емпіричну базу дослідження становлять: аналіз висновків експертів за результатами судововетеринарних експертиз щодо жорстокого поводження 3 тваринами, проведених в Бюро судововетеринарних досліджень Харківської державної зооветеринарної академії протягом 2010-2019 років.
Робота є частиною наукової теми “Теоретикоправові засади судово-ветеринарної експертизи тварин з ознаками жорстокого поводження з ними", яка виконується на базі кафедри ветеринарно-санітарної експертизи та судової ветеринарної медицини Харківської державної зооветеринарної академії. Державний реєстраційний номер - 0118U004677.

\section{Результати та їх обговорення}

Законодавство України щодо захисту тварин від жорстокого поводження поширюється на такі види діяльності, як скотарство, поводження з тваринами на охоронюваних природних територіях, ведення мисливського господарства, полювання, рибальство, розведення, утримання і використання домашніх непродуктивних, а також сільськогосподарських тварин, використання тварин у видовищних заходах, 3 навчально-науковими цілями, у тестуванні та виробництві біологічних препаратів.

Забезпечення тваринам благополуччя, а також їхній захист від жорстокого поводження передбачені міжнародно-правовими нормами, в т. ч. Європейськими конвенціями, зокрема під час розведення та утримання (Свропейська конвенція про захист тварин, що утримуються для сільськогосподарських цілей (що утримуються на фермах), 1976 р.; Європейська конвенція про захист домашніх тварин (1987 р.); перевезення (Свропейська конвенція про захист тварин під час міжнародних перевезень (1968); Свропейська конвенція про захист тварин під час міжнародних перевезень (переглянута), (2003р.), забою тварин (Свропейська конвенція про захист тварин, призначених на забій (1979 р.), проведенні наукових експериментів (Кодекс здоров'я наземних тварин; Свропейська конвенція про захист хребетних тварин, що використовуються для дослідних та інших наукових цілей (1986р.), а також поводження 3 дикими тваринами (Конвенція про збереження тваринного світу і природного середовища існування в Свропі (1979 р.); Конвенція про міжнародну торгівлю видами дикої фауни і флори, що перебувають під загрозою зникнення (1973р.); Міжнародна конвенція щодо регулювання китобійного промислу (1946 р.) (Zubchenko, 2013).

Обіг об'єктів тваринного світу в Україні врегульований Конституцією України, кодифікованими Законами: Цивільним кодексом, Кодексом України про адміністративні правопорушення, Кримінальним кодексом, а також Законами України: “Про ветеринарну медицину” (№ 2498-XII), “Про захист тварин від жорстокого поводження” (№ 3447-IV), “Про ідентифікацію та реєстрацію тварин” (№ 1445-VI), “Про побічні продукти тваринного походження, не призначені для споживання людиною” (№ 1531-VIII), “Про тваринний світ” (№ 2894-III), “Про рибу, інші водні живі ресурси та харчову продукцію 3 них” (№ 486-IV), "Про основні засади державного нагляду (контролю) у сфері господарської діяльності” (№ 877-V), “Про рибне господарство, промислове рибальство та охорону водних біоресурсів” (№ 3677-VI) та ін. 
Провідне значення в сфері регулювання захисту тварин від жорстокого поводження мають однойменні закони (Zakon Ukrainy vid 21.02.2006; Zakon Ukrainy vid 04.08.2017).

На виконання цих законів в Україні прийнято ряд підзаконних нормативно-правових актів:

1) загального характеру: “Щодо поводження з тваринами”. Лист від 04.08.2010 р. № 7/12-8470;

2) під час перебування тварин у притулках: “Ветеринарно-санітарні вимоги до утримання тварин у притулках", затверджені наказом Державного комітету ветеринарної медицини України 15.10.2010 за № 438; "Положення про притулок для тварин”, затверджене наказом Державного комітету ветеринарної медицини України від 15.10.2010 року № 438; "План заходів щодо забезпечення гуманного поводження з безпритульними тваринами”;

3) під час поводження з безпритульними тваринами: “Порядок проведення заходів, необхідних для скорочення чисельності тварин, які становлять небезпеку", затверджений наказом Міністерства охорони навколишнього природного середовища України 28.09.2010 за № 425; Програми регулювання чисельності безпритульних тварин;

4) під час поводження $з$ сільськогосподарськими тваринами: "Порядок використання тварин у сільському господарстві”, затверджений наказом Міністерства аграрної політики та продовольства України 25.10.2012 за № 652 .

5) під час використання експериментальних тварин: "Порядок проведення науковими установами дослідів, експериментів на тваринах”, затверджено наказом Міністерства освіти і науки, молоді та спорту України 01.03.2012 за № 249;

6) під час поводження $з$ дикими тваринами: «Правила і норми утримання дельфінів в умовах неволі», затверджені наказом Міністерства екології та природних ресурсів України 06.12.2012 за № 622; “Про посилення заходів щодо профілактики сказу людей в Україні” (постанова Державного санітарного лікаря України від 18.04.2012, № 7); “Правила використання диких тварин з метою отримання продуктів їх життєдіяльності”, затверджені наказом Міністерства екології та природних ресурсів України 26.09.2011 за № 337; “Порядок утримання та розведення диких тварин, які перебувають у стані неволі або в напіввільних умовах" затверджений наказом Міністерства охорони навколишнього природного середовища України 30.09.2010 за № 429;

7) під час використання тварин у видовищних заходах: "Порядок видачі дозволу на проведення заходів із залученням тварин”, затверджений постановою Кабінету Міністрів України від 22 грудня 2010 р. за № 1175; “Правила використання тварин у видовищних закладах", затверджені наказом Міністерства аграрної політики України 13.10.2010 за № 643; “Щодо дотримання вимог законодавства громадянами, які здійснюють спеціальне використання диких тварин у видовищних заходах та комерційних цілях" (Наказ
Міністерства охорони навколишнього природного середовища України від 20.08.2010 за № 349);

8) під час перевезення тварин: “Правила транспортування тварин”, затверджені постановою Кабінету Міністрів України від 16.11.2011 р. № 1402.

Основоположні правові засади щодо захисту тварин від жорстокого поводження сформульовані в ст. 4 Закону України "Про захист тварин від жорстокого поводження” (Zakon Ukrainy vid 21.02.2006), серед них:

- жорстоке поводження 3 тваринами є несумісним 3 вимогами моральності та гуманності, спричиняє моральну шкоду людині;

- забезпечення умов життя тварин, які відповідають їх біологічним, видовим та індивідуальним особливостям;

- право власності та інші речові права на тварин у разі жорстокого поводження 3 ними можуть бути припинені відповідно до цього Закону;

- заборона жорстоких методів умертвіння тварин;

- відповідальність за жорстоке поводження $з$ тваринами;

- утримання і поводження з домашніми тваринами без мети заподіяння шкоди як оточуючим, так і самій тварині.

Згідно $з$ диспозицією ст. 299 КК України предметом злочину жорстокого поводження з тваринами $\epsilon$ не будь-які тварини, а лише вищі, 3 кістковим хребтом, головним та спинним мозком, периферичною нервовою системою, а також кровоносною системою, незалежно від: належності тварини (приватна, державна, комунальна), умов мешкання (в неволі, природних ареалах), продуктивності (продуктивні, не продуктивні), місця утримання (домашні, агрофірм, дикі, зоопаркові, безпритульні), цілей використання (в кінематографічних, спортивних, видовищних заходах, експериментальних цілях), віку (молоді, зрілі, старі), статі (самці, самки), тривалості (короткочасне, тривале, інтенсивне, мляве), під час певних дій з ними (відтворення й розведення, утримання, годівля, використання, полювання, видовищні заходи, перевезення, підготовка до первинної переробки на бійнях чи інших м'ясопереробних підприємствах, проведення лабораторних досліджень, лікування, евтаназія), стану (порадний, безпорадний).

Криміналізація жорстокого поводження 3 тваринами відбулася у 1988 р. з включенням до Кримінального кодексу України ст. 299, а також встановлено форми прояву цього злочину: знущання чи нацькування тварин одна на одну. I перша, і друга форми характеризуються методами і мотивом вчинення цього злочину. Так, під час знущання чи нацьковування тварин одна на одну може бути присутній хуліганський мотив. Проте знущання може здійснюватися також із застосуванням жорстоких методів (наприклад, обливання тварини сильнодіючими хімічними реагентами; умисне згодовування отрут; дія механічними чи термічними факторами; залишення тварини протягом тривалого часу без їжі, води, доступу повітря; постановка над нею ненаукового експерименту, що спри- 
чиняє іiі страждання тощо), а нацьковування тварин одна на одну може бути вчинене 3 корисних мотивів (наприклад, собачі чи півнячі бої).

За наслідками для здоров'я тварини жорстоке поводження, що не призводить до тілесних ушкоджень, каліцтва чи смерті тягнуть адміністративну відповідальність, згідно зі ст. 89 КУпАП, а якщо такі діяння 3 твариною спричинили каліцтво або смерть, то настає кримінальна відповідальність, згідно зі ст. 299 Кримінального кодексу України.

В нормативно-правових актах України вже кілька раз змінювалось тлумачення дефініції “жорстоке поводження $з$ тваринами". Нами запропонована авторська редакція цієї дефініції (за кримінальної кваліфікації), яка відрізняється від класичного визначення та полягає в тому, що це суспільно-небезпечне, протиправне, винне, каране, умисне, передбачене кримінальним законодавством діяння суб'єкта злочину, яке полягає в умисному посяганні на встановлений порядок утримання та поводження 3 тваринами шляхом безжалісного знущання над твариною із застосуванням жорстоких методів чи з хуліганських мотивів або нацьковування тварин одна на одну, вчинене 3 хуліганських або корисливих мотивів, що спричинило ушкодження, чи інший розлад здоров'я тяжкого ступеня, каліцтво чи смерть тварини.

Новелою дефініції в авторській редакції $є$ те, що нами запропоновано вважати наслідком жорстокого поводження з тваринами не лише каліцтво чи смерть тварини, а й ушкодження чи інший розлад ії здоров'я тяжкого ступеня, яким слід вважати такий стан тварини на момент заподіяння ушкодження, що є небезпечним для життя і загрожує загибеллю тварини; є загроза втрати або відбулася втрата будь-якого органа або втрата органом його функцій; стійке порушення режиму звичного існування (життя) домашньої тварини, стійка втрата здатності до іiі господарського або іншого спеціального використання, або стійкої втрати можливості самостійного існування дикої (безпритульної) тварини в довколишньому середовищі; якщо є загроза або відбулося переривання вагітності; якщо відбулось невиправне знівечення морди чи інших частин тіла.

Небезпечними для життя є ушкодження, що в момент заподіяння (завдання) чи через певний проміжок часу призводять до появи і розвитку загрозливих для організму патологічних процесів і котрі без надання ветеринарної допомоги, за звичайним своїм перебігом, закінчуються чи можуть закінчитися смертю.

До ушкоджень (травм), які $є$ небезпечними для життя тварини, за нашим переконанням, виходячи із досвіду проведення судово-ветеринарних експертиз, належать: проникаючі в черепну порожнину, в тому числі й без ушкодження головного мозку; відкриті й закриті переломи кісток склепіння та основи черепа; будь-які механічні ушкодження головного мозку, а також забиття головного мозку; проникаючі поранення хребта з потраплянням у хребтовий канал, в тому числі й без ушкодження спинного мозку та його оболонок, ушкодження міжхребцевих дисків; переломо- вивих та переломи тіл чи обох дуг шийних хребців, односторонні переломи дуг I або II шийних хребців, а також переломи зубоподібного відростка II шийного хребця, в тому числі без порушення цілісності й функції спинного мозку; вивихи й підвивихи шийних хребців за наявності загрозливих для життя явищ; перелом чи переломо-вивих одного або кількох грудних чи поперекових хребців 3 порушенням функції спинного мозку або з наявністю клінічно встановленого шоку тяжкого ступеня; закриті й відкриті ушкодження спинного мозку, котрі супроводжувались тяжким спинальним шоком чи порушенням функцій органів; ушкодження з повним порушенням цілісності стінки (усіх оболонок) глотки, гортані, трахеї, головних бронхів, стравоходу; закриті переломи під'язикової кістки, закриті й відкриті ушкодження ендокринних залоз, які розташовані в ділянці шиї за наявності загрозливих для життя явищ; поранення грудної клітки, проникаючі в плевральну порожнину, порожнину перикарду чи середостіння, в тому числі й без ушкодження внутрішніх органів; ушкодження черевної стінки, проникаючі в черевну порожнину, в тому числі й без ушкодження внутрішніх органів; відкриті ушкодження внутрішніх органів; закриті ушкодження органів грудної, черевної порожнини, органів ретроперитонеального простору, тазової порожнини - за наявності загрозливих для життя явищ; відкриті діафізарні переломи плечової, стегнової кістки і кісток гомілки; переломи кісток тазу за наявності загрозливих для життя явищ; ушкодження, що спричинили шок тяжкого ступеня, масивну крововтрату, коматозний стан, гостру органну чи поліорганну недостатність, недостатність кровообігу, гормональну дисфункцію, гострі розлади регіонарного і органного кровообігу, жирову чи газову емболію; ушкодження великих кровоносних судин; ушкодження, спричинені місцевим впливом високої температури за наявності загрозливих для життя явищ; ушкодження, спричинені впливом іонізуючих випромінювань за наявності загрозливих для життя явищ; ушкодження у вигляді опіків, спричинених концентрованими розчинами їдих хімічних речовин за умови, що в клінічному перебігу мали місце загрозливі для життя явища; усі види механічної асфіксії (Yatsenko et al., 2019).

На нашу думку, необхідність включення до наслідків жорстокого поводження з твариною такої категорії, як ушкодження чи інший розлад ії здоров'я тяжкого ступеня зумовлена тим, що ст. 299 КК України захищає моральні засади суспільства в частині ставлення до тварин, а із переліку ознак ушкодження тварини тяжкого ступеня випливає, що вони можуть бути завдані тварині шляхом особливої жорстокості, безжалісного, цинічного і немилосердного ставлення до них, а отже - спричиняє загрозу для суспільної моральності. Небезпека цього злочину полягає і в тому, що жорстокість, проявлена щодо тварин, стає нормою поведінки, поширюється і на взаємини 3 людьми, відіграє негативну роль у вихованні молоді (Yatsenko \& Kyrychenko, 2014). 
В нашій судово-експертній практиці трапляються випадки, коли тварині були спричинені тілесні ушкодження, що за ознаками відповідали тяжкому ступеню (Yatsenko et al., 2019), проте ознаки каліцтва в такої постраждалої тварини при цьому були відсутні, а тому суб’єкт, котрий спричинив тварині тяжкі травми, не піддавався кримінальному переслідуванню, оскільки такий вид діяння (ушкодження тварини чи інший розлад їі здоров'я тяжкого ступеня) нині не передбачений ст. 299 КК України.

В процесі виконання цієї роботи нами проаналізовано висновки експертів і висновки експертних досліджень щодо жорстокого поводження 3 тваринами протягом 2010-2019 років, отримані з архіву Бюро

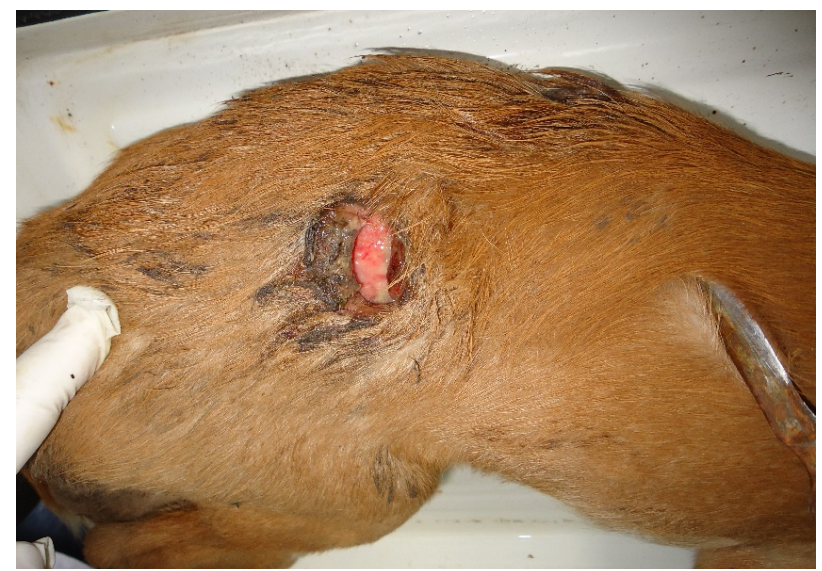

Рис. 3. Розрив від різкого удару тупим предметом 3 обмеженою поверхнею. Макрофото.

(Із архіву Бюро судово-ветеринарних досліджень ХДЗВА, 2018)

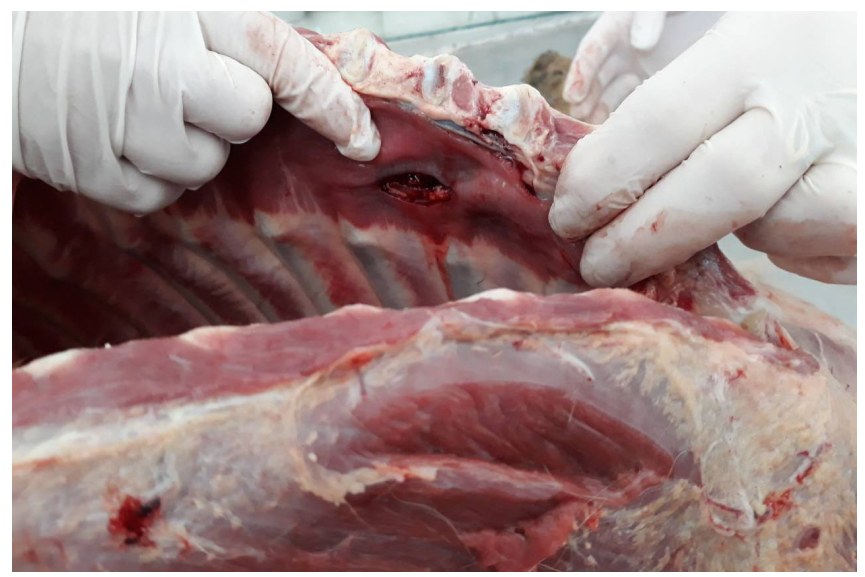

Рис. 5. Судово-ветеринарне дослідження трупа собаки “Буран": проникаюча рана бічної грудної клітки справа. Макрофото. (Із архіву Бюро судововетеринарних досліджень ХДЗВА, 2017) судово-ветеринарних досліджень Харківської державної зооветеринарної академії (Yatsenko et al., 2018).

Під час опрацювання зазначених висновків нами встановлені способи вчинення винними цього діяння. Серед таких зареєстровані ушкоджень тупим предметом (40,4 \%) (рис. 3-4), гострим і колючим предметом $(5,3 \%)$ (рис. 5-6), у вигляді вогнепальної травми $(7,0 \%)$ (рис. 7), отруєння протитуберкульозними препаратами і зоокумаринами (1,8 \%) (рис. 8), ушкодження полум'ям (1,8 \%) (рис. 9), повішення (стронгуляційна асфіксія) (1,8 \%), задушення (3,5\%), моріння голодом $(35,1 \%)$, падіння 3 висоти $(3,5 \%)$ (рис. 10).

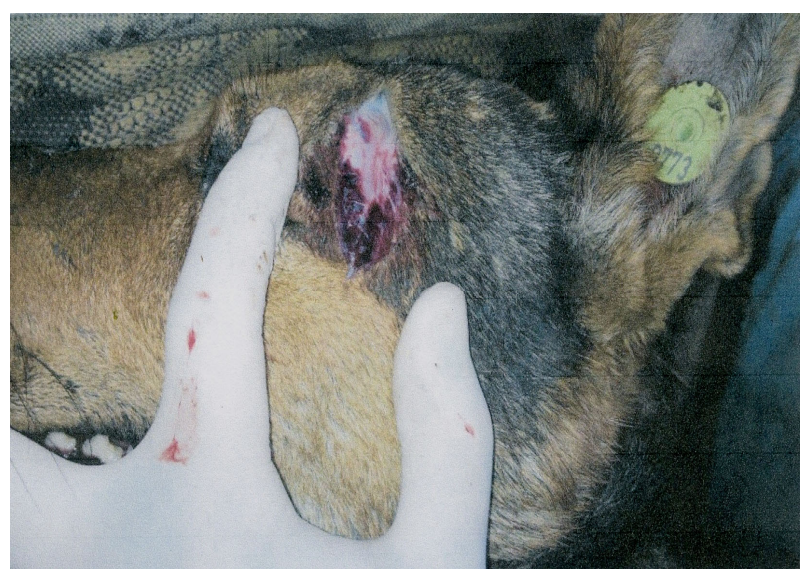

Рис. 4. Рана в ділянці лівої очної орбіти собаки внаслідок ушкодження тупим предметом. Макрофото. (Із архіву Бюро судово-ветеринарних досліджень ХДЗВА, 2017)

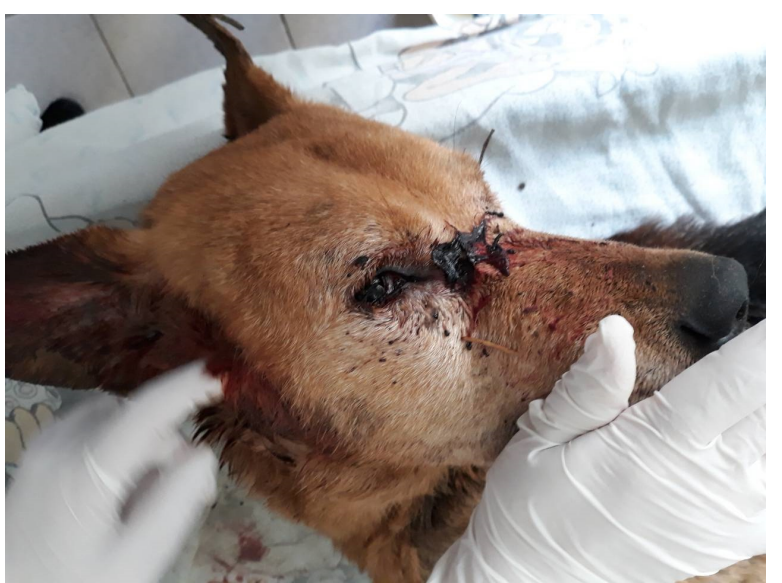

Рис. 6. Судово-ветеринарне дослідження трупа собаки “Буран”: розчавлення і часткове травматичне видалення правого ока від удару ломом. Макрофото. (Із архіву Бюро судововетеринарних досліджень ХДЗВА, 2017) 


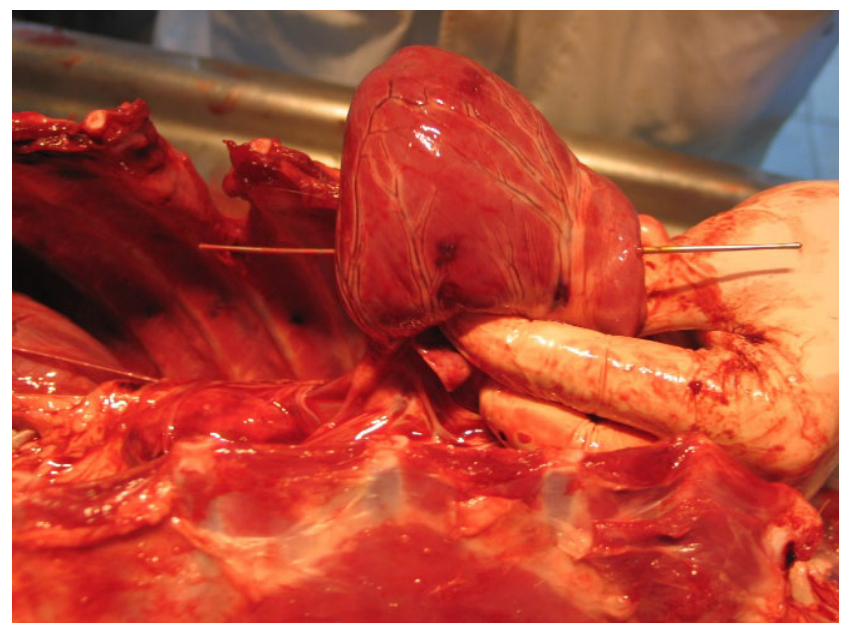

Рис. 7. Вогнепальні ушкодження, виявлені в трупі собаки "Кінг”: серце з наскрізними ранами. Макрофото. (Із архіву Бюро судово-ветеринарних досліджень ХДЗВА, 2011)

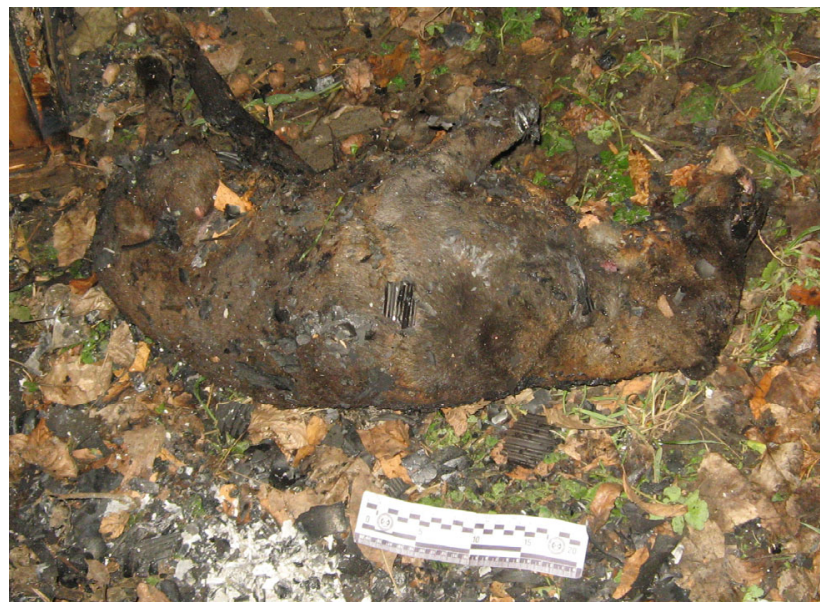

Рис. 9. Труп собаки з ознаками опікової травми. Макрофото. (Із архіву Бюро судово-ветеринарних досліджень ХДЗВА, 2014)

Аналіз вищезгаданих висновків експертів дозволив встановити знаряддя вчинення цього злочину. Так, найбільшу частку серед них склали підручні побутові предмети (73,9 \%), серед яких лопата, лом, молоток, ніж, вила; меншу частку становить вогнепальна зброя $(17,4$ \%) і найменшу - мотузка для повішення $(4,3 \%)$ та полум'я $(4,3 \%)$.

Найбільш поширеним $є$ злочин жорстокого поводження з собаками (57,1 \%), дещо меншим - 3 котами $(41,1 \%)$ і найменше - 3 сільськогосподарськими тваринами, зокрема великою рогатою худобою $(1,8 \%)$.

Одними з об'єктів судово-ветеринарної експертизи за жорстокого поводження є живі тварини. Проте нормативно-правові акти, котрі б врегульовували алгоритм проведення судово-ветеринарної експертизи живих тварин нині відсутні. Судово-ветеринарна

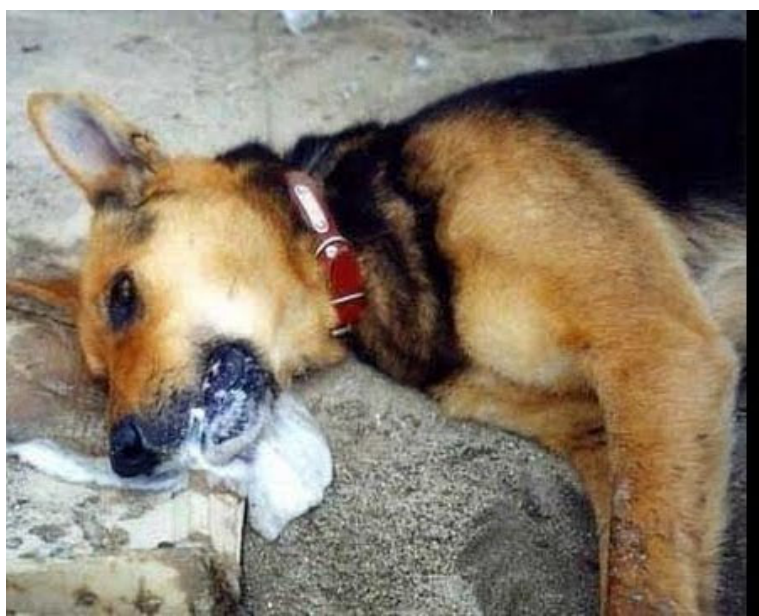

Рис. 8. Труп собаки, смерть якого настала від отруєння ізоніазидом. Макрофото. (Із архіву Бюро судово-ветеринарних досліджень ХДЗВА, 2013)

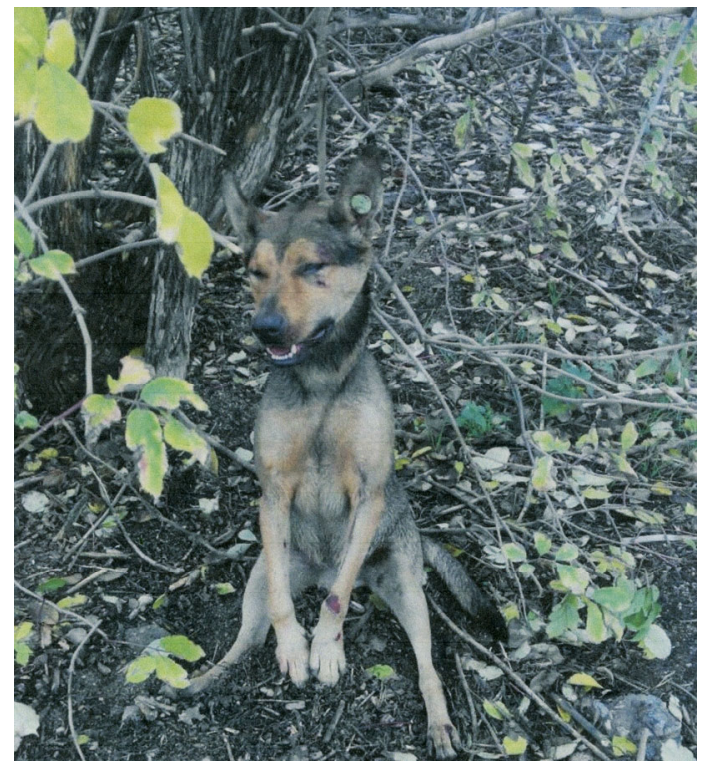

Рис. 10. Загальний вигляд трупа собаки, згідно 3 протоком ОМП. Механічна асфіксія шляхом здавлювання шиї петлею. Макрофото. (Із архіву Бюро судово-ветеринарних досліджень ХДЗВА, 2017)

експертиза чи експертне дослідження живих тварин, постраждалих від жорстокого поводження 3 ними, проводиться в закладах, які мають спеціальне ветеринарне призначення. В процесі роботи над цією проблемою нами запропоновано дещо розширений алгоритм судово-ветеринарного клінічного дослідження тварини одночасно зі збільшенням кількості досліджуваних експертом ознак, зокрема він корелює із переліком питань, які можуть бути поставлені судововетеринарному експерту для проведення експертизи тварин, постраждалих від жорстокого поводження: встановлення розпізнавальних ознак тварини (вид, стать, порода, маса тіла, колір волосся, кличка, інвентарний номер, фізіологічні особливості та ін.), дослідження тілесних ушкоджень, виявлених у тварини; обгрунтування механізму їх спричинення, давності, 
черговості, послідовності, насильницького характеру виникнення; встановлення причинно-наслідкового зв'язку між виявленими ушкодженнями і заподіяними тварині тілесними ушкодженнями; встановлення виду знарядь травми за характером травм, а також 3'ясування питання, чи спричинили виявлені ушкодження біль, страждання і мучення тварини (Yatsenko et al., 2018). Особлива увага звертається на описання status localis за запропонованими нами схемами, які придатні саме для судово-ветеринарних досліджень, що і відрізняє їх від схем клінічного дослідження хворої тварини.

Крім живих тварин, об'єктом судово-ветеринарної експертизи є трупи або частини трупів тварин, що загинули за будь-якого виду насильницької смерті, в т. ч. постраждалих від жорстокого поводження (Wobeser, 1996). На цьому етапі роботи ми адаптували схему патологоанатомічного дослідження трупа тварин, існуючу у ветеринарній медицині, до вимог судово-ветеринарної експертизи та удосконалили іiі системою ознак. Так, судово-ветеринарна експертиза трупа тварини складається з таких етапів:

1) ознайомлення $з$ документом про призначення експертизи (ухвалою суду, ухвалою судді, постановою слідчого) та 3 іншими доданими до нього матеріалами (копією протоколу огляду місця події, випискою з амбулаторного журналу тощо);

2) складання плану проведення судововетеринарної експертизи трупа тварини;

3) зовнішнє та внутрішнє дослідження трупа, вилучення органів, тканин та біологічних рідин для лабораторних досліджень;

4) лабораторне дослідження вилучення органів, тканин та біологічних рідин;

5) комплексна оцінка результатів дослідження трупа тварини на підставі результатів судововетеринарного дослідження, отриманих лабораторних даних, матеріалів провадження та ветеринарної документації;

6) складання експертного документа (висновку експерта, експертного дослідження, повідомлення про неможливість надання висновку) 3 відповідями на питання, що були поставлені на вирішення експерту.

Запропонований нами орієнтовний перелік питань може бути поставлений на вирішення судововетеринарному експерту судом чи слідчим, надасть можливість встановити розпізнавальні ознаки трупа тварини (до якого виду належить труп тварин $(u)$; якої статі, віку труп(u) тварин(u), яка маса трупа, які його фізіологічні особливості, хто був власником чи опікуном тварини), дослідити тілесні ушкодження в трупі тварини, обгрунтувати механізм ї спричинення, а також з'ясувати танатологічні закономірності; встановити причинно-наслідковий зв'язок між виявленими ушкодженнями i смертю тварини; а також з'ясувати, чи спричинили виявлені ушкодження біль, страждання і мучення тварини перед смертю; чи могли бути спричинені виявленні ушкодження результатом насильницьких дій над твариною (Yatsenko et al., 2019).
За результатами теоретичного обгрунтування алгоритму судово-ветеринарного дослідження трупа тварини нами розроблено авторську комп'ютерну програму "Судово-ветеринарна танатологія - SVT" для автоматизації й оптимізації процесів оформлення протоколу судово-ветеринарного розтину трупа тварини, а відповідно й висновку експерта.

Результати проведеної роботи судововетеринарним експертом оформляються у вигляді таких процесуальних документів: висновку експерта або експертного дослідження; повідомленні про неможливість надання висновку, згідно з Законом України "Про судову експертизу" (Pro sudovu ekspertyzu, 1994), а також згідно з “Інструкцією про призначення та проведення судових експертиз та експертних досліджень" (Instruktsiia pro pryznachennia i provedennia sudovykh ekspertyz, 1998).

Висновок судово-ветеринарного експерта підписує експерт, котрий проводив експертизу. Його підпис скріпляється печаткою установи, в якій виконана експертиза. Додатки до експертизи оформляють у вигляді фототаблиць. Висновок судово-ветеринарного експерта має відповідати таким вимогам: бути обгрунтованим і об'єктивним, правильним і правдивим, мотивованим (Repeshko, 2004).

Таким чином, в результаті цілеспрямованих і систематично проведених досліджень на підставі узагальнення власного судово-експертного досвіду та аналізу експертної практики в Україні й світі нами обгрунтовано низку важливих пропозицій, здатних позитивно вплинути на формування нормативноправової бази щодо організації і проведення судововетеринарних експертиз в Україні, ефективність проведення судово-ветеринарної експертизи за жорстокого поводження $з$ тваринами, надання обгрунтованого, об'єктивного, правдивого висновку експерта, зокрема:

- проаналізовано експертну практику проведення судово-ветеринарних експертиз і досліджень тварин за жорстокого поводження з ними;

- сформульовані теоретичні розробки можна покласти в основу підготовки “Правил судововетеринарного визначення ступеня тяжкості тілесних ушкоджень”, “Правил судово-ветеринарної експертизи живих тварин”, “Правил судово-ветеринарної експертизи трупа тварини”;

- розроблено й обгрунтовано судово-ветеринарні критерії визначення ступеня тяжкості тілесних ушкоджень тварин в т. ч. й за жорстокого поводження;

- сформульовано й теоретично обгрунтовано загальні оргінізаційно-правові засади та розроблено алгоритм проведення судово-ветеринарної експертизи живих тварин та трупів тварин за жорстокого поводження $з$ ними;

- розкрито особливості оформлення результатів судово-ветеринарної експертизи тварин, постраждалих від жорстокого поводження;

- запропоновано питання, які можуть бути поставлені суддями чи слідчими на вирішення судовому 
експерту під час виконання судово-ветеринарної експертизи живих тварин чи трупів тварин;

- сформульовано напрями вдосконалення судововетеринарної експертизи за жорстокого поводження 3 тваринами.

Удосконалено:

- дефініцію терміну жорстокого поводження 3 тваринами через наведення його в авторській редакціï, що має вплинути на його більш чітке наукове розуміння;

- алгоритми клінічного ветеринарного дослідження живих тварин та трупа тварини з ознаками насильницької смерті від жорстокого поводження.

Дістали подальшого розвитку:

- концепція судово-ветеринарної експертизи за жорстокого поводження з тваринами;

- обгрунтування щодо необхідності розробки i впровадження в практику спеціальних нормативноправових актів, котрі забезпечать реалізацію розроблених нами алгоритмів судово-ветеринарної експертизи трупів тварин з ознаками насильницької смерті, а також живих тварин, постраждалих від жорстокого поводження.

Практичне значення наших розробок полягає в тому, що їх можна застосовувати в:

- правотворчості - для подальшого вдосконалення національного кримінального законодавства щодо злочинів проти суспільної моральності, зокрема ст. 299 ККУ, шляхом введення в диспозицію понять «ушкодження від жорстокого поводження $з$ тваринами тяжкого ступенів», передбачивши одночасно й санкцію, відповідно до ступеня тяжкості тілесних ушкоджень;

- правозастосовній діяльності - для вдосконалення методик розслідування злочинів проти суспільної моральності, зокрема за ст. 299 ККУ для здійснення правильної кваліфікації такого злочину; вироблення алгоритму взаємодії суду, слідчого й судововетеринарного експерта; удосконалення структури і змісту ст. 299 КК України, а також в процесі підготовки та практичної діяльності фахівців правоохоронних органів;

- експертній практииі - для проведення судововетеринарної експертизи живих тварин, постраждалих від жорстокого поводження чи трупів тварин з ознаками насильницької смерті від жорстокого поводження;

- навчальному прочесі - під час викладання й вивчення на юридичних факультетах навчальних дисциплін: "Кримінальне право”, “Кримінальний процес”, “Судова експертиза”, а також на факультетах ветеринарної медицини дисциплін: "Патологічна анатомія та розтин”, “Судова ветеринарна медицина», “Ветеринарне правознавство”.

Результати наших теоретичних і практичних розробок знайшли відображення в практичних рекомендаціях. Таким чином, фахівцям юристам під час розслідування правопорушень щодо жорстокого поводження 3 тваринами, а також лікарям судововетеринарним експертам під час проведення судово- ветеринарної експертизи живих тварин, постраждалих від жорстокого поводження, чи трупів тварин з ознаками насильницької смерті від жорстокого поводження, рекомендуємо:

- користуватися запропонованими нами судововетеринарними критеріями визначення ступеня тяжкості тілесних ушкоджень тварин за жорстокого поводження (легкого, середнього, тяжкого);

- підготувати "Правила судово-ветеринарного визначення ступеня тяжкості тілесних ушкоджень" на основі розроблених нами судово-ветеринарних критеріїв визначення ступеня тяжкості тілесних ушкоджень тварин за жорстокого поводження з ними (Yatsenko et al., 2019);

- використовувати удосконалений нами алгоритм клінічного ветеринарного дослідження під час судово-ветеринарного дослідження тварин, постраждалих від жорстокого поводження з ними;

- використовувати запропонований нами алгоритм судово-ветеринарної експертизи трупа тварини 3 ознаками насильницької смерті від жорстокого поводження;

- використовувати розроблену авторську комп'ютерну програму “Судово-ветеринарна танатологія - SVT' для автоматизації й оптимізації процесів оформлення протоколу судово-ветеринарного розтину трупа тварини;

- використовувати запропоновані нами питання, які можуть бути поставлені на вирішення судововетеринарної експертизи живих тварин чи трупів тварин слідчими під час укладання постанови про призначення експертизи, клопотання до слідчого судді, а також слідчими суддями під час складання ухвали на призначення судово-ветеринарної експертизи;

- використовувати результати досліджень у навчальному процесі для підготовки лекцій, лабораторних занять, для написання навчально-методичної літератури із кримінального і адміністративного права, кримінального і цивільного процесу, судової ветеринарної медицини та патологічної анатомії тварин, біоетики на юридичних факультетах та факультетах ветеринарної медицини;

- внести доповнення до "Науково-методичних рекомендацій з питань підготовки і призначення судових експертиз" запропонований нами орієнтовний перелік питань, які можуть бути поставлені на вирішення судово-ветеринарного експерта під час призначення судово-ветеринарної експертизи живих тварин та трупів тварин з ознаками насильницької смерті від жорстокого поводження.

\section{Висновки}

Напрями вдосконалення судово-ветеринарної експертизи живих тварин, постраждалих від жорстокого поводження, чи трупів тварин з ознаками насильницької смерті від жорстокого поводження є розробка, затвердження і впровадження в практику нормативноправових актів щодо судово-ветеринарного визначення ступеня тяжкості тілесних ушкоджень, судово- 
ветеринарної експертизи живих тварин, судововетеринарної експертизи трупа тварини, автоматизації й оптимізації процесів оформлення результатів експертизи, використання новітніх інформаційних технологій в судово-ветеринарній експертизі.

Кваліфікація правопорушення жорстокого поводження $з$ тваринами має враховувати висновок судово-ветеринарного експерта щодо характеру та ступеня тяжкості тілесних ушкоджень, а також причиннонаслідковий зв'язок між виявленими експертом ушкодженнями і розладом здоров'я, каліцтвом чи смертю тварини.

За жорстокого поводження $з$ тваринами виключно судово-ветеринарний експерт за результатами проведеної судово-ветеринарної експертизи констатує: причину смерті тварини, характер, локалізацію, черговість, послідовність і механізм ушкоджень, визначає ступінь тяжкості тілесних ушкоджень, а також встановлює причинно-наслідковий зв'язок між тілесними ушкодженнями і розладом здоров'я чи смертю постраждалої тварини.

Наслідком жорстокого поводження 3 тваринами $є$ не лише каліцтво чи смерть тварини, а й ушкодження чи інший розлад ії здоров'я тяжкого ступеня.

Запропонований нами орієнтовний перелік питань, які можуть бути поставлені на вирішення судововетеринарного експерта судом чи слідчим під час дослідження живої тварини, постраждалої від жорстокого поводження чи трупа тварини з ознаками насильницької смерті (Yatsenko et al., 2019), необхідно внести як доповнення до “Науково-методичних рекомендацій з питань підготовки і призначення судових експертиз та експертних досліджень” для їх практичного використання правоохоронними органами.

Перспективи подальших досліджень. В подальшому плануємо розробити та обгрунтувати теоретичну основу окреслених напрямів вдосконалення судово-ветеринарної експертизи тварин, постраждалих від жорстокого поводження, а також застосувати їх в експертній практиці.

\section{References}

de Almeida Silva, T. T. (2016). The Constitutional Defense of Animals in Brazil. Animal law and welfare international perspectives, 53, 181-193. doi: 10.1007/978-3-319-26818-7 9.

Allegri, F. (2019). What Animal Ethics? Four Options in Comparison. Ragion pratica, 51(2), 611-634. doi: 10.1415/95167.

Antoniuk, D. O. (2014). Zhorstoke povodzhennia z tvarynamy: poniattia ta oznaky skladu zlochynu. Chetverti kharkivski kryminalno-pravovi chytannia: tezy dopovidei. Kharkiv: Pravo. 373-376 (in Ukrainian).

Bradley-Siemens, N., \& Brower, A. I. (2016). Veterinary Forensics: Firearms and Investigation of Projectile Injury. Veterinary pathology, 53(5), 988-1000. doi: $10.1177 / 0300985816653170$.
Benetato, M. A., Reisman, R., \& McCobb, E. (2011). The veterinarian's role in animal cruelty cases. Javmajournal of the american veterinary medical association, 238(1), 31-34. doi: 10.2460/javma.238.1.31.

Cooper, J. E., \& Cooper, M. E. (1998). Future trends in forensic veterinary medicine. Seminars in avian and exotic pet medicine, 7(4), 210-217. doi: 10.1016/S1055-937X(98)80066-2.

Cooper, J. E., \& Margaret, M. E. (2008). Forensic veterinary medicine: a rapidly evolving discipline. Forensic science medicine and pathology, 4(2), 75-82. doi: 10.1007/s12024-008-9036-x.

Chorna, O. S. (2010). Deiaki aspekty kryminalnoi vidpovidalnosti za zhorstoke povodzhennia $\mathrm{Z}$ tvarynamy. Materialy Mizhnarodnoi naukovoi konferentsii "Zlochynnist u sferi profesiinoi diialnosti. Deviati yurydychni chytannia". Odesa, 148-150 (in Ukrainian).

Denysov, S. F., \& Kulyk, Yu. S. (2003). Kryminalnopravova kharakterystyka zhorstokoho povodzhennia $\mathrm{z}$ tvarynamy. Visnyk Zaporizhskoho yurydychnoho instytutu, 3(24), 186 (in Ukrainian).

Gerdin, J. A., \& McDonough, S. P. (2013). Forensic Pathology of Companion Animal Abuse and Neglect. Veterinary pathology, 50(6), 994-1006. doi: $10.1177 / 0300985813488895$.

Holovko, I. A. (2010). Kryminalna vidpovidalnist za zhorstoke povodzhennia $\mathrm{z}$ tvarynamy: avtoref. dys.... k.iu.n.: 12.00.08. Kyiv, 20 (in Ukrainian).

Instruktsiia pro pryznachennia i provedennia sudovykh ekspertyz (Nakaz Ministerstva yustytsii Ukrainy vid 08.10 .1998 r. № 53/5 (u redaktsii nakazu Ministerstva yustytsii Ukrainy vid 26.12.2012 № 1950/5) (in Ukrainian).

Kalmykov, D. O., \& Danylevskyi, A. O. (2013). Kryminalna ta administratyvna vidpovidalnist za zhorstoke povodzhennia $\mathrm{z}$ tvarynamy: monohrafiia. Luhansk (in Ukrainian).

Landina, A. V. (2005). Kryminalno-pravova okhorona moralnosti v Ukraini: avtoref. dys. ... k.iu.n. : 12.00.08. Kyiv: Instytut derzhavy ta prava (in Ukrainian).

Lobov, Y. Y. (2000). Otvetstvennost za zhestokoe obrashchenye s zhyvotnymi. Uholovnoe pravo, 2, 31 (in Russian).

Lockwood, R., Touroo, R., Olin J., \& Dolan, E. (2019). The Influence of Evidence on Animal Cruelty Prosecution and Case Outcomes: Results of a Survey. Journal of forensic sciences, 64(6), 1687-1692. doi: 10.1111/1556-4029.14085.

Medytskyi, I. B. (2014). Perspektyvy udoskonalennia kryminalnoho zakonodavstva v chastyni vidpovidalnosti za zhorstoki formy povedinky $\mathrm{z}$ tvarynamy. Polityka v sferi borotby zi zlochynnistiu. Ivano-Frankivsk, 87-90 (in Ukrainian).

McEwen, B. J. (2012). Trends in Domestic Animal Medico-Legal Pathology Cases Submitted to a Veterinary Diagnostic Laboratory 1998-2010. Journal of forensic sciences, 57(5), 1231-1233. doi: 10.1111/j.15564029.2012.02123.x. 
Priest, C. (2019). Law and social inquiry. Journal of the american bar foundation, 44(1), 136-169. doi: 10.1017/1si.2018.11.

Pro zakhyst tvaryn vid zhorstokoho povodzhennia: Zakon Ukrainy vid 21.02.2006 № 3447-IV (in Ukrainian).

Pro vnesennia zmin do deiakykh zakonodavchykh aktiv Ukrainy shchodo zaprovadzhennia humannoho stavlennia do tvaryn: Zakon Ukrainy vid 04.08.2017. № 2120-VIII (in Ukrainian).

Pro sudovu ekspertyzu: Zakon Ukrainy. Vidomosti Verkhovnoi Rady Ukrainy (VVR), 1994, № 28, st. 232 (in Ukrainian).

Repetskyi, S. P. (2010). Suspilna moralnist yak obiekt kryminalno-pravovoi okhorony : avtoref. dys. ... k.iu.n. 12.00.08 - kryminalne pravo ta kryminolohiia; kryminalno-vykonavche pravo. Kyiv, 22 (in Ukrainian).

Repeshko, P. I. (2004). Shchodo rehlamentatsii vymoh do vysnovku sudovoho eksperta u zakonodavstvi Ukrainy. Teoriia ta praktyka sudovoi ekspertyzy i kryminalistyky. Kharkiv: Pravo, 36-39 (in Ukrainian).

Shumilo, O. O. (2016). Kryminolohichna kharakterystyka ta zapobihannia zhorstokomu povodzhenniu $\mathrm{Z}$ tvarynamy: dysertatsiia ... k.iu.n. 12.00.08 kryminalne pravo ta kryminolohiia; kryminalnovykonavche pravo. Kharkiv, 206 (in Ukrainian).

Statychna zvitnist Upravlinnia orhanizovanoho zabezpechennia YeRDR ta informatsiino-analitychnoi roboty Heneralnoi prokuratury Ukrainy. [Elektronnyi resurs] Rezhym dostupu: https://www.gp.gov.ua/ua/stst2011. html?dir_id=113653 \&libid $=100820 \& c=$ edit\&_c=fo.

de Siqueira, A., Cuevas, S. E. C., Salvagni, F. A., \& Maiorka, P. C. (2016). Forensic Veterinary Pathology: Sharp Injuries in Animals. Veterinary pathology, 53(5), 979-987. doi: 10.1177/0300985816655850.

Traini, C. (2019). The Liberal Order and the Animals: The Origins of Animal Advocacy in the Western World. Ricerche di storia politica, 22(3), 307-316. doi: 10.1412/95049.

Turska, V. O. (2016). Administratyvno-pravove rehuliuvannia zakhystu tvaryn vid zhorstokoho povodzhennia: dys. ... k.iu.n.: 12.00.07. Odesa, 232 (in Ukrainian).

Verbitska, M. V. (2014). Yurydychna vidpovidalnist za zhorstoke povodzhennia iz tvarynamy. Naukovyi visnyk Khersonskoho derzhavnoho universytetu.
Seriia "Iurydychni nauky". Kharson, 1(3), 9-14 (in Ukrainian).

Ward, S. J., \& Hosey, G. (2019). The Need for a Convergence of Agricultural/Laboratory and Zoo-based Approaches to Animal Welfare. Journal of applied animal welfare science. doi: 10.1080/10888705.2019.1678038.

Wobeser, G. (1996). Forensic (medico-legal) necropsy of wildlife. Journal of wildlife diseases, 32(2), 240-249. doi: 10.7589/0090-3558-32.2.240.

Yatsenko, I. V., Zapara, S. I., Zakhariev, A. V., Skrypka, M. V., \& Serdiukov, Ya. K. (2018). Sudovo-ekspertni vypadky doslidzhennia trupiv tvaryn z oznakamy nasylnytskoi smerti vid zhorstokoho povodzhennia. Problemy zooinzhenerii ta veterynarnoi medytsyny, 36(2), 130-138 (in Ukrainian).

Yatsenko, I. V., \& Kyrychenko, V. M. (2014). Suspilna nebezpeka ta obiektyvna storona zlochynu zhorstokoho povodzhennia $\mathrm{z}$ tvarynamy $\mathrm{v}$ aspekti sudovo-veterynarnoi ekspertyzy. Problemy zooinzhenerii ta veterynarnoi medytsyny, 28(2), 259272 (in Ukrainian).

Yatsenko, I. V., Parylovskyi, O. I., \& Kolomoiets, D. K. (2019). Obhruntuvannia pytan, shcho stavliatsia V ukhvali sudu ta postanovi slidchoho pry pryznachenni sudovo-veterynarnoi ekspertyzy trupa tvaryny $\mathrm{z}$ oznakamy nasylnytskoi smerti vid zhorstokoho povodzhennia. Veterynariia, tekhnolohii tvarynnytstva ta pryrodokorystuvannia: naukovo-praktychnyi zhurnal, 4, 184-197 (in Ukrainian).

Yatsenko, I. V., Parylovskyi, O. I., \& Kolomoiets, D. K. (2019). Pravyla sudovo-veterynarnoho vyznachennia stupenia tiazhkosti tilesnykh ushkodzhen tvaryn, postrazhdalykh vid zhorstokoho povodzhennia. Svidotstvo pro reiestratsiiu avtorskoho prava na tvir № 94868 (in Ukrainian).

Zapara, S. I., Fotina, H. A., Klochko, A. M., Fotina, T. I., \& Yatsenko, I. V. (2019). Revisiting legal understanding of wild life as a sustainable value (the case of Ukraine). Journal of Environmental Management and Tourism, 10(1), 14-21 (in Ukrainian).

Zubchenko, N. Y. (2013). Sravnitelno-pravovoi analiz zakonodatelstva hosudarstv $\mathrm{v}$ sfere obrashcheniia $\mathrm{s}$ zhyvotnymi. Ukrainskyi chasopys mizhnarodnoho prava: naukovo-praktychnyi zhurnal. Spetsvypusk: Mizhnarodno-pravovi standarty povodzhennia $\mathrm{z}$ tvarynamy ta yikh zakhystu i praktyka Ukrainy. Kyiv: IMV Kyivskoho nats. un-tu im. Tarasa Shevchenka, 80-83 (in Russian). 